\title{
EVALUATION OF E-RESOURCES IN MADURAI KAMARAJ UNIVERSITY LIBRARY: A USER-CENTRED APPROACH TOWARDS COLLECTION DEVELOPMENT
}

\author{
Maheswari.S1, Aravind.S 2 \\ ${ }^{1}$ Research Scholar, Department of Library and Information Science, \\ Madurai Kamaraj University, Madurai and Librarian, \\ Mangayarkarasi College of Arts and Science for Women, Madurai, India \\ Email Id: s.maheswari21@yahoo.com \\ ${ }^{2}$ Librarian and Head, \\ Department of Library and Information Science, \\ G.T.N. Arts College, Dindigul - 624005, Tamilnadu, India \\ Email Id:aragtn2601@yahoo.com
}

\section{Manuscript Info}

\section{Manuscript History}

Received: 03 November 2020

Final Accepted: 22 December 2020

Published: 10 January 2021

Online Published: February 2021

DOI: http://dx.doi.org/10.35337/EIJLITR.2021.1202

Corresponding Author E-mail:

s.maheswari21@yahoo.com (Maheswari.S)

aragtn2601@yahoo.com (Aravind.S)

(c) Maheswari.S Aravind.S The Author. This is an open access article under the terms of the Creative Commons Attribution License 4.0, which allows use, distribution and reproduction in any medium, provided the original work is properly cited.

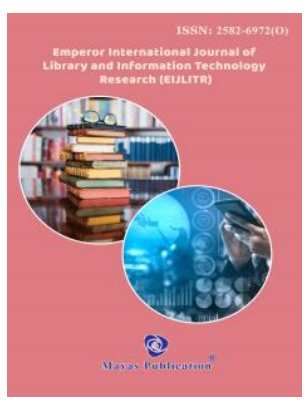

\section{Abstract}

University Libraries play an indispensable role in promoting higher education by developing varied resource collections and providing multiple services. Since the resources are meant for the users, their perception about the different collection is very significant. This paper examines the evaluation if electronic resources by users of Madurai Kamaraj University Library. The study is intended to know the user satisfaction level regarding the various types of E-Resources which can be used as a tool in collection development. A survey was conducted among the respondents and the study format that majority of the users rated EResources in the library as Good and they were satisfied to a large extent with these resources.

Keywords: E-Resources, Evaluation, Collection Development 


\section{INTRODUCTION}

Libraries of higher education institutes cater to the educational and research needs of its scholarly community. These libraries therefore require resources that satisfy the teaching, learning and academic activities of its clientele. While building and updating resources it is necessary to understand the existing collection. Evaluation of resources reveals how the collection meets the requirements of the users and the remedial measures required for improvements. Evaluation can be qualitative or quantitative and the approach can be user-centred or collection -centred. Qualitative analysis is a subjective approach as it is based on the perception and understanding of the user. A survey using questionnaire was used in the study to evaluate the E-Resource collection of Madurai Kamaraj University Library in Tamil Nadu state.

\section{LITERATURE REVIEW}

Mansur (2012) described electronic resources as electronic products that deliver a collection of data, be it text referring to full text databases, e-journals, e-books, image collections, other multimedia products and numerical, graphical or time based, as commercially available title that has been published with a sole aim of being marketed and for information dissemination. These may be delivered on any optical media or via the Internet. (Beals \& Gilmour, 2007) assessed monographic collections in zoology in three academic libraries using Brief test method and World Cat collection analysis. They found that both methods are useful to access narrow and broad subject areas and also for any type or size of collection.

\section{Madurai Kamaraj University Library}

Madurai Kamaraj University Library commenced its services in 1974. It has a fairly good collection of Books, Journals, Theses, Bound Volumes of Periodicals, E-Journals, Databases, Popular Magazines and Newspapers. The open access digital library of Ph.D. provides full text of all theses awarded by the university. The library has an ETD (Electronic Theses \& Dissertation) lab to digitise the theses and has created a Madurai studies collection and Journal article index which is an index to articles in the Journals subscribed by the library buy not available through Internet.

\section{OBJECTIVES OF THE STUDY}

$>$ To find out the rating of various electronic resources by the respondents.

$>$ To find out the rating on various features of E-Resources by the respondents.

$>$ To find out the satisfaction level of the respondents with regard to the information.

$>$ Flow in their subject areas.

$>$ To find out the problems faced by users while accessing E-Resources.

\section{Methodology}

A survey was conducted among the respondents. Hundred structures questionnaire were distributed to Research Scholars and students to know their opinion about various E-Resources of the Library. 96 duly filled questionnaire were received back indicating the response rate was above $90 \%$. 
Survey Analysis

Discipline-wise distribution of respondents

Table 6.1.1

Discipline-wise distribution of respondents

\begin{tabular}{|l|c|c|}
\hline \multicolumn{1}{|c|}{ Discipline } & No. of Respondents & Percentage(\%) \\
\hline Arts & 18 & 18.75 \\
\hline Science & 34 & 35.41 \\
\hline Humanities & 16 & 16.67 \\
\hline Social Sciences & 28 & 29.17 \\
\hline No. of Respondents & 96 & 100 \\
\hline
\end{tabular}

The table shows that the highest number of respondents were from Science faculty $(35.41 \%)$ followed by Social Sciences (29.17\%) Arts (18.75\%) and Humanities (16.67\%)

Discipline-wise distribution of respondents

Table 6.2.1

Discipline-wise Distribution of Respondents

\begin{tabular}{|l|c|c|}
\hline Qualification & No. of Respondents & Percentage(\%) \\
\hline PG & 56 & 58.33 \\
\hline M.Phil & 22 & 22.92 \\
\hline Ph.D. & 15 & 15.63 \\
\hline Others & 3 & 3.12 \\
\hline Total & 96 & 100 \\
\hline
\end{tabular}

The table shows that majority of the respondents (58.33\%) were PG students followed by M.Phil (22.92\%), Ph.D (15.63\%) and others (3.12\%).

\section{Rating on E-Resources}

Table 6.3.1

Rating on E-Resource

\begin{tabular}{|l|c|c|c|c|c|}
\hline \multicolumn{1}{|c|}{ E-Resources } & Excellent & Very Good & Good & Average & Poor \\
\hline E-Books & $16(16.66)$ & $22(22.91)$ & $41(43.16)$ & $6(6.25)$ & $3(3.12)$ \\
\hline E-Journals & $19(19.79)$ & $37(38.54)$ & $29(30.20)$ & $4(4.16)$ & $0(0)$ \\
\hline E-Full Text Database & $7(7.29)$ & $26(27.08)$ & $43(44.79)$ & $9(9.37)$ & $0(0)$ \\
\hline E-Bibliographic Database & $3(3.12)$ & $25(26.04)$ & $34(35.41)$ & $22(22.91)$ & $0(0)$ \\
\hline E-Theses & $10(10.41)$ & $36(37.5)$ & $29(30.53)$ & $7(7.37)$ & $3(3.12)$ \\
\hline E-Reference & $9(9.37)$ & $16(16.84)$ & $37(38.54)$ & $20(20.83)$ & $2(2.08)$ \\
\hline
\end{tabular}


Highest number of respondents (43.16\%) rated E-Books as Good, second highest $(22.91 \%)$ rated Very Good followed by $(16.66 \%)$ rating Excellent, only a small percentage $(6.25 \% \& 3.12 \%)$ rated Average and Poor. E-Journals were rated Very Good by more respondents $(38.54 \%)$ Good by $(30.20 \%)$ Excellent by (19.79\%) Average by a very small number $(4.16 \%)$ and Poor by none. More respondents $(44.79 \%)$ rated EFull Text Database and E-Bibliographic database (35.41\%) as Good while almost equal number of respondents rated very Good, none rate Poor. Theses were rated Very Good by (37.5) and Good by $(30.53 \%)$ whereas $((10.41 \%)$ rated Excellent. E-Reference was rated Good by largest number $(38.54 \%)$ followed by second largest rating Average. Overall it is understood that the highest number of respondents rated E-Resources as Good.

\section{Rating on features of E-Resources}

Table 6.4.1

\section{Rating on features of E-Resources}

\begin{tabular}{|l|c|c|c|c|c|}
\hline E-Resources Features & Excellent & Very Good & Good & Average & Poor \\
\hline Adequacy & $9(9.37)$ & $28(29.16)$ & $41(43.16)$ & $5(5.26)$ & $2(2.08)$ \\
\hline Quality & $17(17.71)$ & $25(26.31)$ & $39(40.62)$ & $5(5.26)$ & $0(0)$ \\
\hline Currency & $7(7.29)$ & $29(30.21)$ & $41(43.16)$ & $8(8.33)$ & $0(0)$ \\
\hline Relevance & $10(10.53)$ & $34(35.79)$ & $36(37.5)$ & $5(5.26)$ & $0(0)$ \\
\hline Coverage & $3(3.12)$ & $34(35.79)$ & $38(39.58)$ & $9(9.37)$ & $2(2.08)$ \\
\hline Completeness & $5(5.26)$ & $33(34.74)$ & $33(34.74)$ & $14(14.58)$ & $0(0)$ \\
\hline
\end{tabular}

The highest number of respondents $(43.16 \%)$ rated the Adequacy of E-Resource collection Good whereas the second highest $(29.16 \%)$ rated Very Good and $(9.37 \%)$ rated Excellent, only $(2.08 \%)$ rated Poor. Similarly more number of respondents $(40.62 \%)$ rated the Quality of collection as Good followed by $(26.31 \%)$ rating Very Good $(17.71 \%)$ rating Excellent and none rating Poor. Regarding Currency also the first two ratings follow the same pattern followed by (8.33) rating Average and (7.29) rating Excellent none ratings poor. Relevance of E-Resources was also rated Good by maximum respondents (37.5) Very Good $(35.79 \%)$ whereas $(10.53 \%)$ rated Excellent and (5.26\%) Average. Coverage was rated Good and Very Good by $(39.58 \%$ \& $35.79 \%)$ respectively. The quality of Completeness was rated Very Good and Good by an equal number of respondents (34.74\%) whereas (14.58\%) rated Average and only (5.26\%) Excellent, none rated Poor. Overall majority of respondents were satisfied with the features of EResource collection.

\section{Satisfaction with Information flow}

Table 6.5.1

Satisfaction with Information flow

\begin{tabular}{|l|c|c|}
\hline Satisfaction Level & No. of Respondents & Percentage (\%) \\
\hline Very Large Extent & 5 & 5.20 \\
\hline Large Extent & 38 & 39.58 \\
\hline Some Extent & 24 & 25 \\
\hline Less Extent & 0 & $(0)$ \\
\hline Very Less Extent & 0 & $(0)$ \\
\hline
\end{tabular}

Regarding satisfaction with information flow provided by various E-Resources in their subject areas highest percentage (39.58\%) reported that they were satisfied to a Large Extent and second highest (25\%) reported that they were satisfied to Some Extent. A small percentage $(5.20 \%)$ reported that they were 
satisfied to Very Large Extent where as none reported that they were satisfied to Less Extent. Overall majority seemed satisfied with the information flow in their respective fields.

\section{Problems faced while accessing E-Resources}

Table 6.5.1

Satisfaction with Information flow

\begin{tabular}{|l|c|c|}
\hline Problem & No. of Respondents & Percentage (\%) \\
\hline Slow Speed & 32 & 33.33 \\
\hline Periodic network down & 36 & 37.5 \\
\hline Information overload & 10 & 10.41 \\
\hline Difficulty in finding relevant information & 33 & 34.37 \\
\hline Lack of Professional help & 18 & 18.75 \\
\hline
\end{tabular}

Majority of the respondents revealed that periodic network down was the main problem faced by them while accessing E-Resources whereas (33.33\%) \& (34.37\%) reported Slow Speed and Difficulty in finding relevant information as their problems respectively. Almost $(18.75 \%)$ reported lack of professional assistance and $(10.41 \%)$ reported information overload as their problem.

\section{FINDINGS}

The following findings were drawn from the evaluation

> Majority of the respondents were from Science faculty $(35.41 \%)$ followed by Social Sciences (29.17\% ) Arts (18.75\% ) and Humanities ( $16.67 \%)$

$>$ Most of the respondents (58.33\%) were Post Graduate students followed by M.Phil (22.92\%), Ph.D. Scholars $(15.63 \%)$ and others (3.12\%).

$>$ Majority of the respondents rated E-Resources as Good.

> Most of the respondents rated the features of E-Resources as Good and Very Good.

$>$ Highest percentage $(39.58 \%)$ were satisfied to a large extent by the information flow in their subject areas where as none were satisfied to less extent.

$>$ Majority of the respondents revealed that periodic network down was the main problem faced while accessing E-Resource followed by slow speed and difficulty in finding relevant information.

\section{CONCLUSION}

The result indicated that majority of the users rated E-Resources as Good and they were satisfied to a large extent with the information flow in their subject areas. They also had to face few problems like periodic network down, slow speed, difficulty in finding relevant information, information overload and at times lack of professional support. But in spite of all these drawbacks users were satisfied with the EResources of the university library. 


\section{REFERENCE}

1. Mansur, S (2012). E-resources collection development in engineering college libraries: a challenge for knowledge centre managers. International Journal of Digital Library Services, 2(1), 166-177 Retrieved from. http://www.aca

2. Agee, Jim. "Collection Evaluation: a Foundation for Collection Development" Collection Building 24, no.3 (2005): 92-95.

3. Beals, Jennifer Benedetto, and Ron Gilmour: "Assessing Collections using Brief Tests and Worldcat Collection Analysis." Collection Building 26, no.4 (September 2007): 104-7.

4. Borin, Jacqueline, and Hua Yi. "Assessing an Academic Library Collection through Capacity and Usage Indicators: Testing a Multi-Dimensional Model." Collection Building 30 no. 3 (May 2011): 120-25.

5. Ciszek, Matthew P., and Courtney L. Young. "Diversity Collection Assessment in Large Academic Libraries." Collection Building 29, no.4 (December 2010): 154-61. 